\title{
Editorial
}

\section{Ansiedade antraz}

Como definir o "espírito do momento" nos Estados Unidos? $\mathrm{O}$ horror indignado e sofrido das primeiras semanas foi substituído por outro sentimento generalizado, que me interessa compreender. Estresse, ansiedade, pânico: são algumas das palavras que têm aparecido na mídia local. Na cobertura da imprensa brasileira, além desses termos, encontrei paranóia, histeria e doença sociogênica.

Estresse constitui uma noção confusa, pouco específica e inadequada para o entendimento desse fenômeno de massa. A pátria da competitividade orgulha-se de cultivar e de gerenciar estresses crônicos como fator de progresso. Paranóia e histeria referem-se a conceitos da psicopatologia clássica, demasiadamente específicos e valiosos para ser desperdiçados em sua acepção do senso comum. E, com certeza, não há pânico social. Falta caos para tanto. De fato impressiona o esforço que esse país faz para normalizar a vida. Mesmo a corrida às farmácias (até atravessando fronteiras) para armazenar medicamentos e a enorme freqüência de falsos alarmes provocados por pós com cores suspeitas e pela presença de pessoas têm acontecido de modo organizado, sem pandemônios.

Do ponto de vista epidemiológico, síndrome sociogênica coletiva é o mais interessante desses conceitos. Há diversos relatos de sintomatologia de massa compartilhada por estudantes e grupos profissionais nas principais cidades norte-americanas. Um número ainda não mensurado de pessoas, principalmente jovens e mulheres, tem apresentado um quadro neurológico incapacitante, aparentemente contagioso, porém benigno. No que pese o arsenal clínico e laboratorial utilizado, nenhum microorganismo ou causa ambiental tem sido imputado como responsável pelos sintomas. Pode ser interessante examinar o registro histórico de surtos epidêmicos dessa natureza.

No ano de 1918, ocorreu uma epidemia desse tipo na Bahia, cujos principais sintomas eram perda de visão e uma fraqueza muscular aguda, provocando quedas súbitas. A Gazeta Médica da Bahia, na época uma das principais publicações científicas do país, relatou em detalhe a semiologia da doença, parecida com os casos observados nos EUA. Porém, o que impressiona é o grau de semelhança dos respectivos contextos. Em 1918, o Brasil acabara de entrar na Primeira Guerra Mundial. O porto de Salvador pela primeira vez recebia navios de guerra aliados; a cidade estava repleta de soldados e marinheiros; as famílias locais se preparavam para enviar seus filhos para uma guerra distante. Para completar o quadro, uma epidemia de gripe espanhola grassava em todo o país (onde acabaria causando mais de 300 mil mortes), ameaçando principalmente cidades portuárias como Salvador. O povo soteropolitano batizou sua estranha síndrome sociogênica coletiva de caruara. $\mathrm{O}$ episódio deixou uma "cicatriz lingüística": ainda hoje, em nosso dialeto baiano, caruara quer dizer incômoda fraqueza nas pernas, que ocorre nos momentos mais tensos da vida, principal sintoma de um medo atroz.

Em Cuba, início da década de 90, fim da Guerra Fria (e, apesar disso, manutenção do infame bloqueio diplomático e comercial imposto pelos Estados Unidos), 50 mil pessoas foram acometidas de um quadro neurológico altamente incapacitante, com sintomas agudos de fadiga e perda da acuidade visual. Nenhuma lesão ou microorganismo foi identificado, porém a maioria dos casos experimentou recuperação em poucos meses. Sem muita comprovação, atribuiu-se a misteriosa neuropatia epidêmica à carência nutricional generalizada dos primeiros meses de racionamento, que se seguiram à súbita retirada dos subsídios soviéticos e ao bloqueio total da ilha. Porém, há algo mais nessa história. Na época, Cuba experimentava uma severa epidemia de dengue, com numerosos casos da forma hemorrágica e muitas mortes. A despeito de se tratar de um território isolado geográfica e politicamente, a epidemia havia eclodido simultaneamente em pontos distantes da ilha. Epidemiologistas cubanos e outros latino-americanos consideraram esse padrão incompatível com epidemias naturais, lançando-se a suspeita de guerra bacteriológica.

Não obstante as ironias históricas, algo se passa, reprime-se e se constrói nos "corações e mentes" deste povo. (É de propósito que uso tal expressão, emprestada de um glossário ainda atual na língua nativa, mera evocação da Guerra do Vietnã). Creio que uma síndrome sociogênica coletiva está se instalando. As pessoas temem por tudo e por todos, parentes e pessoas queridas, tempos e eventos, lugares que deixaram de freqüentar, hábitos perdidos ou suprimidos. Evidentemente, há uma base factual para tal sentimento, desencadeada pelos atos terroristas de setembro e pela contaminação do antraz, reforçada por uma profunda penetração midiática no cotidiano de todos. Percebo um medo geral, denso e difuso, crônico e contagioso. Um imenso medo contido. Porém um imperativo cívico responde à pátria ameaçada, resguardando laços sociais, e reprimindo, ao máximo, o sentimento de pânico. Foi assim na Bahia em 1918 e em Cuba em 1992-1993. É curioso que, como pano de fundo das três situações, ocorrem epidemias de agentes biológicos.

Como todos, procuro respostas, fico ainda mais atento. Novamente é a televisão, esse excepcional veículo de acesso a um imaginário fragmentado, que me serve de oráculo: uma emissora intitula um bloco do seu noticiário como Anthrax anxiety. Tradução para o nosso idioma: Ansiedade antraz. Encontro nesse jogo de palavras um nome para o sentimento que percebo: os americanos padecem de ansiedade atroz. Ou, em bom baianês, caruara.

Naomar de Almeida Filho Universidade Federal da Bahia e Harvard School of Public Health 